\title{
$\nabla$
}

\section{Vellus hair cysts presenting as an atypical acneiform eruption *}

\section{Cisto de pelo velos apresentando-se como erupção acneiforme atípica}

\author{
Hiram Larangeira de Almeida Jr. ${ }^{1}$ \\ Joice Göebel ${ }^{3}$ \\ Juliana Hein ${ }^{3}$
}

Lisia Nudelmann ${ }^{2}$

Nathália Janovik ${ }^{3}$

\begin{abstract}
A 32-year-old male patient presented for 8 months an asymptomatic therapy-resistant acneiform eruption on his back and buttocks. Skin examination showed several inflammatory papules, which evolved to hyperpigmentation. At the same distribution non inflammatory papules, which resembled rice grains, were also observed. Light microscopy showed small keratin-filled cysts, with an epithelial multilayered wall, without granular layer. Keratin and some vellus hairs were identified inside the cyst, confirming the diagnosis of vellus hair cysts. Diagnosis of vellus hair cysts should be suspected in cases of multiple papules or therapy-resistant cases of acneiform eruptions.
\end{abstract}

Keywords: Acne vulgaris; Acneiform eruptions; Follicular cyst; Isotretinoin; Young adult; Keratins

Resumo: Um paciente de 32 anos apresentou há 8 meses uma erupção acneiforme resistente à terapêutica, localizada no dorso e nádegas. Ao exame apresentava inúmeras pápulas inflamatórias, que evoluiam para hiperpigmentação. Na mesma distribuição havia lesões não inflamatórias, lembrando grão de arroz. A microscopia óptica demonstrou cisto dérmico cuja parede era de epitélio estratificado, sem camada granular, preenchido de queratina e com pelos no interior, confirmando o diagnóstico de cisto de pelo veloso. Essa entidade deve ser suspeitada em casos de múltiplas pápulas ou erupções acneiformes resistentes à terapia.

Palavras-chave: Acne vulgar; Adulto jovem; Cisto folicular; Erupções acneiformes; Isotretinoína; Queratinas

\section{INTRODUCTION}

Vellus hair cysts is a rare condition which has no racial or gender predisposition. It normally affects adolescents or young adults and could be sporadic or autosomal dominant. ${ }^{1,2,3}$ This term was used for the first time by Esterly and cols in 1977, who described two pediatric patients with multiple monomorphic asymptomatic hyperchromic papules on the trunk and extremities. ${ }^{2,4}$

\section{CASE REPORT}

A 32-year-old male patient presented an asymptomatic acneiform eruption on his back and buttocks for 8 months. He was treated with benzoyl peroxide, topical antibiotics and oral isotretinoin with no response. Skin examination showed inflammatory papules, which resolved with hyperpigmentation
(Figure 1). At the same distribution non inflammatory papules, which resembled rice grains, were also observed. One of these papules was removed and light microscopy showed a small keratin-filled cyst, with an epithelial multilayered wall, without granular layer (Figures $2 \mathrm{~A}$ and $2 \mathrm{~B}$ ). Some vellus hairs were identified inside the cyst, confirming the diagnosis of vellus hair cyst (Figure 2C).

\section{DISCUSSION}

The pathogenesis of vellus hair cysts is not fully understood, probably development abnormalities of this peculiar small follicle, which is typically found outside from scalp and face, lead to occlusion and dilatation of the follicular unit 3. Moreover mutations in the gene that codifies keratin 17 were described. ${ }^{5}$

Recebido em 16.06.2010.

Aprovado pelo Conselho Consultivo e aceito para publicação em 04.07.2010.

* Trabalho realizado no Departamento de Dermatologia, Universidade Federal de Pelotas - Pelotas (RS), Brasil.

Conflito de interesse: Nenhum / Conflict of interest: None

Suporte financeiro: Nenhum / Financial funding: None

Livre Docente - Prof. Assistente das Universidades Federal e Católica de Pelotas (UFPEL-UCPEL) - Pelotas (RS), Brasil

Médica - Residente de Dermatologia da Santa Casa de Misericórdia de Porto Alegre - Porto Alegre (RS), Brasil.

Acadêmica de Medicina da Universidade Federal de Pelotas (UFPEL) - Pelotas (RS), Brasil.

(C)2011 by Anais Brasileiros de Dermatologia 


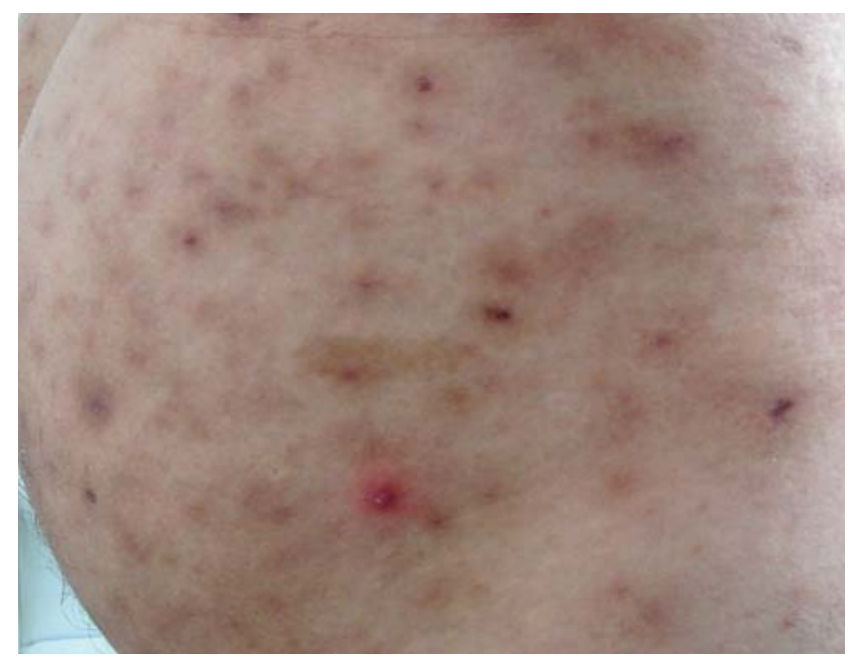

FIGURE 1: Clinical features with inflammatory papules and hyperpigmentation

This condition is characterized by multiple normochromic or hyperpigmented papules, ranging from 1 to $5 \mathrm{~mm}$, that appear mainly on the chest and extre- mities; rarely abdomen, neck, axillae and face may be involved. ${ }^{6,7}$ They may undergo inflammatory changes and be misdiagnosed as acne, as in the case here described.

Diagnosis should be suspected in cases of multiple papules or therapy-resistant cases of acne. It can be confirmed by light microscopy, which shows the dermal keratinized cysts with hairs in their interior. ${ }^{7,8}$

Differential diagnoses include steatocystoma multiplex, milium, moluscum contagiosum, other cysts (infundibular, trichilemmal, epidermal), folliculitis and acne. ${ }^{4,8,9}$ Spontaneous remission occurs in 25 $\%$ of the cases, due to transepidermal elimination or inflammatory destruction. Treatment is a challenge, with no response to oral isotretinoin. ${ }^{3,8}$ There are some reports of improvement with dermabrasion, $\mathrm{CO}_{2}$ Laser and needle incision, but the large number of lesions may preclude complete resolution. ${ }^{3,10}$ There is only one report of non-inflammatory vellus hair cysts in the Brazilian literature, different from our case, which had an inflammatory onset. ${ }^{11}$
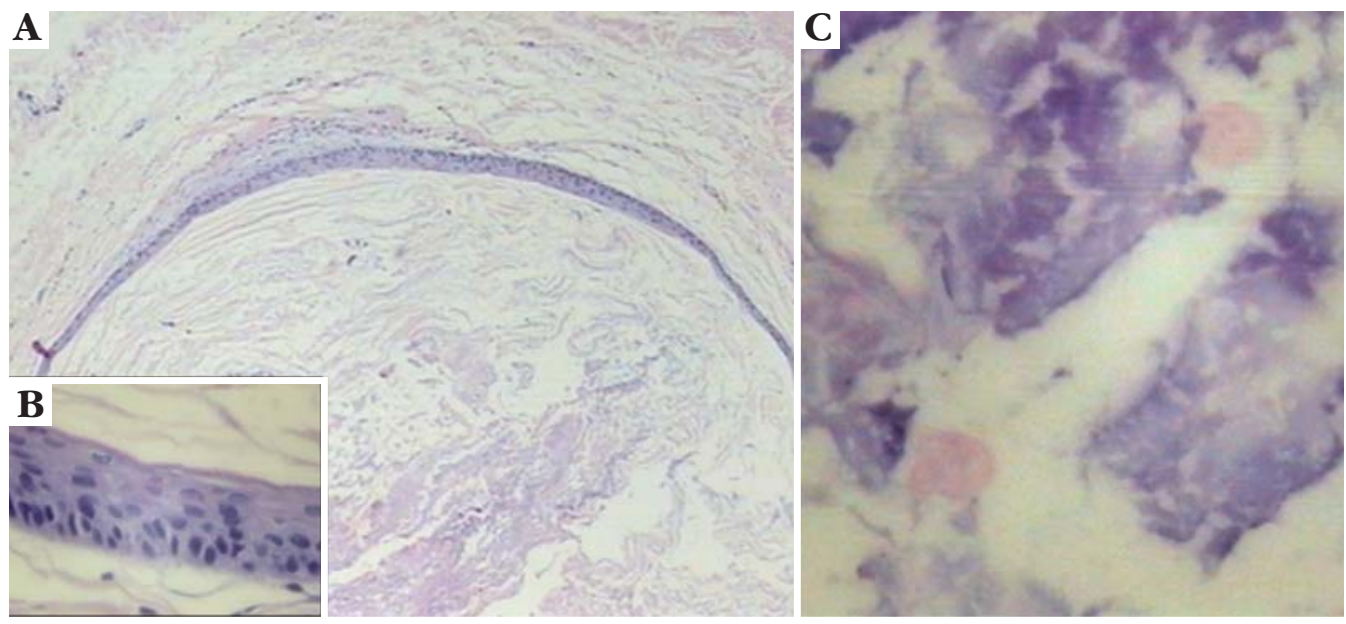

Figure 2: A. dermal cyst; B. detail of cyst wall, with a multilayered epithelium; C. hairs inside the cyst

\section{REFERENCES}

1. Reep MD, Robson KJ. Eruptive vellus hair cysts presenting as multiple periorbital papules in a 13-year-old boy. Pediatr Dermatol. 2002;19:26-7.

2. Esterly NB, Fretzin DF, Pinkus H. Eruptive vellus hair cysts. Arch Dermatol. 1977;113:500-3.

3. Karen JK, Heller M, Wee SA. Eruptive vellus hair cysts. Dermatol Online J. 2007;13:14

4. Baums K, Peytavi UB, Dippel E, Goerdt S, Orfanos CE. Eruptive vellus hair cysts. Eur J Dermatol. 2000;10:487-9.

5. Tomkova H, Fujimoto W, Arata J. Expression of keratins (K10 and K17) in steatocystoma multiplex, eruptive vellus hair cysts, and epidermoid and trichilemmal cysts. Am J Dermatopathol. 1997;19:250-3.

6. Kwon KS, Lee HT, Jang HS, Chung TA, Oh CK. A case of generalized eruptive vellus hair cysts. J Dermatol. 1997;24:556-7.

7. Hong SD, Frieden IJ. Diagnosing eruptive vellus hair cysts. Pediatr Dermatol. 2001;18:258.

8 Karadag AS, Cakir E, Pelitli A. Eruptive vellus hair cysts: An alternative diagnosing method. Indian J Dermatol Venereol Leprol. 2009;75:537-8.
9. Yamada A, Saga K, Jimbow K. Acquired multiple pilosebaceous cysts on the face having the histopathological features of steatocystoma multiplex and eruptive vellus hair cysts. Int J Dermatol. 2005;44:861-3.

10. Coras B, Hohenleutner U, Landthaler M, Hohenleutner S. Early recurrence of eruptive vellus hair cysts after Er: YAG laser therapy: case report and review of the literature. Dermatol Surg. 2005;31:1741-4.

11. Ayres EL, Quattrino AL, Rochael MC. Cisto eruptivo de pêlo velos. An Bras Dermatol. 1997;72:155-8.

MAILING ADDRESS / ENDEREÇO PARA CORRESPONDÊNCIA:

Hiram Larangeira de ALmeida Jr.

Rua General Osório, 385 - Centro.

96020-000 Pelotas - RS

E-mail: hiramalmeidajr@botmail.com

How to cite this article/Como citar este artigo: Almeida Jr HL, Nudelmann L, Göebel J, Janovik N, Hein J. Vellus hair cysts presenting as an atypical acneiform eruption. An Bras Dermatol. 2011;86(4):789-90. 